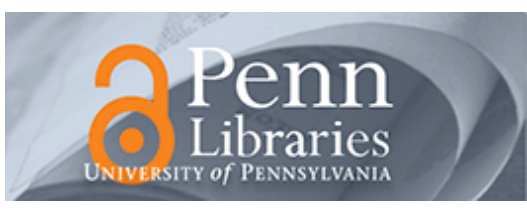

University of Pennsylvania
ScholarlyCommons

Department of East Asian Languages and

Civilizations

School of Arts and Sciences

2011

\title{
Is There Such a Thing as Central/Inner (Eur)Asia and Is Mongolia a Part of It?
}

Christopher P. Atwood

University of Pennsylvania, catwood@sas.upenn.edu

Follow this and additional works at: https://repository.upenn.edu/ealc

Part of the East Asian Languages and Societies Commons

\section{Recommended Citation (OVERRIDE)}

Atwood, C. P. (2011). Is There Such a Thing as Central/Inner (Eur)Asia and Is Mongolia a Part of It?. In P. L. W. Sabloff (Ed.), Mapping Mongolia: Situating Mongolia in the World from Geologic Time to the Present (pp. 60-84). Philadelphia, PA: University of Pennsylvania Press.

At the time of publication, author Christopher P. Atwood was affiliated with Indiana University. Currently, he is a faculty member in the East Asian Languages and Civilizations Department at the University of Pennsylvania.

"Mapping Mongolia: Situating Mongolia in the World from Geologic Time to the Present" is a collection of papers originally presented at a conference held in Philadelphia, May 6-11, 2007.

This paper is posted at ScholarlyCommons. https://repository.upenn.edu/ealc/17

For more information, please contact repository@pobox.upenn.edu. 


\section{Is There Such a Thing as Central/Inner (Eur)Asia and Is Mongolia a Part of It?}

\section{Disciplines}

Arts and Humanities | East Asian Languages and Societies

\section{Comments}

At the time of publication, author Christopher P. Atwood was affiliated with Indiana University. Currently, he is a faculty member in the East Asian Languages and Civilizations Department at the University of Pennsylvania.

"Mapping Mongolia: Situating Mongolia in the World from Geologic Time to the Present" is a collection of papers originally presented at a conference held in Philadelphia, May 6-11, 2007. 


\title{
Is There Such a Thing as Central/Inner (Eur)Asia and Is Mongolia a Part of It?
}

\author{
CHRISTOPHER P. ATWOOD
}

$\mathrm{T}$ o the informed reader today, the vast area between Russia, the Middle East, India, and China's Han heartland is still all Central Asia. Scholars studying the area, however, find this term frustratingly polyvalent. In years of addressing various audiences, I have found that as a rule it is perilous to use "Central Asia" without giving a strict and specific definition. This confusion stems from the sedimentation of different historical usages, none of which has replaced the other. Thus someone speaking about Central Asia might be using the term according to Edwardian English, or as a translation of either of two distinct terms originally designed in Russian to be opposite and complementary, or using the language of social science or current United States policy interests. As a result of this ambiguity, I have joined many other academics in preferring to use "Inner Asia," "Central Eurasia," or else much more specific terms_ "Tibeto-Mongolian," "the steppe belt," and so on. This confusion of usage raises the question, though, is the broad concept of Central Asia/Inner Asia/Central Eurasia useful? And if so, as a Mongolist I have to ask, does Mongolia belong to it? Lurking behind all these questions is the bigger one of whether area studies and the broad concepts used to structure them, such as "Central Asia," "the Middle East," "East Asia," or "Islam" have a future. Or do they need to be replaced by other concepts such as "-scapes?” In the conclusion I would like to suggest 
that paradoxically it is "area studies" concepts which often express nonacademic intuitions more closely, and "-scapes" that are valuable analytically, but at a rather recondite academic level.

\section{“CENTRAL ASIA”AND ITS PERMUTATIONS}

In British English, at least, the phrase "Central Asia" and its cognates originated in the reorganization of geographical conceptions of the generalized "East" or "Orient" sparked by the advent of mass ocean travel. The term "Far East" came to be used in its current sense of China, Japan, and Southeast Asia in the 1850s, and the more specific terms "Near East" and "Middle East" (which originally often included India) were then defined in relation to the "Far East" by the 1890s. ${ }^{1}$

"Central Asia," however, was only ambiguously part of this East, newly defined by maritime accessibility. From the 14th century at least up to the 1890 s, the lands of the steppes and the Altaic-speaking peoples had regularly been called Tartary, a name derived ultimately from the Mongol Empire. ${ }^{2}$ As memories of the Mongol Empire were overlain by more contemporary interests in the East (within which inland Asia was a backwater), Tartary came to be defined not by a people or a history but by its position on the map of Asia. From the 1840s to the 1890s, the broad area of landlocked Asia was often designated "High Asia" a term that vividly captured what travelers felt going from the plains of India or China up into mountains of Afghanistan, Tibet, or Mongolia. ${ }^{3}$ The term Central Asia can be found in the present sense at least as far back as 1850 , but it only came into its own in English usage with the creation of the Royal Central Asian Society in 1901. ${ }^{4}$ Central and High Asia were broad terms covering all the countries inland from India, China proper, and the Middle East, and unlike Tartary they also included Tibet and the Himalayas. This broad usage of Central Asia for all of inland Asia-from Iran's northeastern Khorasan province, Kashmir, Nepal, and Bhutan north to Kazakhstan, Southern Siberia, and Mongolia (Inner and Outer) - is today rare in scholarly contexts; its major recent use was in the UNESCO History of Civilizations of Central Asia project (UNESCO 1998).

Since the Russians came to rule much of the area, they, too, had an interest in precise terminology. Eventually they used two rather clearly defined terms to divide the region. One was a very specific region they called 
Sredniaia Aziia, literally "Middle Asia," that included present-day Turkmenistan, Uzbekistan, Tajikistan, and parts of Kyrgyzstan. What unified this region was a geography divided into oases and deserts, its urban Islamic and Turco-Persian culture, and its status as a newly acquired part of the Russian Empire, mostly ruled through the client emirates of Bukhara and Khiva. Before the Russian conquest, these lands had been known to the Greeks as Transoxania (Land beyond the Oxus), to the Arabs as Mawarannahr (Land Beyond the River), and to the Iranians as Turan, a term used in the Persian national epic Shahnameh for the hostile lands beyond the Oxus/ Amu Darya. From the 16th century on, the Uzbek rulers of Bukhara took over this literary sounding name of Turan for their own country. But later the new Russian rulers adopted the term Turkestan (Land of the Turks) for their new province, even though many of the inhabitants still spoke Iranian languages such as Tajik. Thus a term which had originally designated the largely nomadic lands north and east of Transoxania/Mawarannahr/Turan came to designate the urban centers of civilization of Bukhara and Samarqand (Levi 2002:8-12).

The rest of what the British called Central Asia was rather Tsentral'naia Aziia (Central Asia), a term that for the Russians included the Chinese imperial dependencies: Tuva, the Mongolian banners (Inner and Outer), Chinese Turkestan (Xinjiang), Kökenuur (Qinghai), and Tibet. The steppe lands of Kazakhstan were sometimes treated as part of Siberia, sometimes left on their own, and sometimes affiliated with Central Asia; they were rarely considered part of Middle Asia. Instead, Middle Asia and Kazakhstan became a common Soviet locution for what English writers would later call "the -stans."

Given the close intellectual ties between Russia and Germany, the terms Middle Asia and Central Asia went into German directly as Mittelasien and Zentralasien, respectively, with roughly the same connotations. The fairly sharp distinction between Middle Asia and Central Asia among the muchtranslated writings of Russian travelers and scholars might have generated some greater precision in the English-speaking world, except that both were always translated "Central Asia." Likewise, both terms were translated in French and Chinese in the same way: Asie centrale and Zhōng Yàxìyà. Only in a few specialized academic venues was the Soviet distinction maintained, usually by narrowing "Central Asia" to fit the Russians' "Middle Asia" and then choosing some other term ("Inner Asia" or "Central Eurasia") to cover the original English-speaking world's broad "Central Asia." 
Faced with confusion in journalistic and geographical usage, scholars attempted to carve out their own special terms. The term Inner Asia was first given currency by Owen Lattimore's Inner Asian Frontiers of China (1940). As Lattimore's title implied, the term was used in contrast to China, and thus, like Russian Tsentral'naia Aziia and German Zentralasien meant in his hands the Qing Dynasty dependencies of China from 1755 to 1911: Mongolia (Inner and Outer), Tuva, Xinjiang or Chinese Turkestan, Kökenuur, and Tibet. Its literal meaning, as the inner or landlocked portion of Asia, made it easy, however, to extend the term to all of Edwardian "Central Asia" or any subpart thereof. Thus a book like Svat Soucek's A History of Inner Asia, which focused on Asia's landlocked Turco-Iranian regions, shares only Xinjiang with the original "Inner Asia" of Owen Lattimore (Kotkin 2007:499 n.39). Greater historical depth and cultural consistency were attained by Denis Sinor's coinage "Central Eurasia," which could include the Caspian and Black Sea steppes, and even his native Hungary by adding Eur- to Asia. ${ }^{5}$

"Eurasia" as a term was suddenly catapulted into currency with the breakup of the Soviet empire in 1991-but in a way quite different in connotation from the Eurasia of Central Eurasia. A new term was needed for the occasions when "former Soviet Union" was too cumbersome and backward-looking, and for many journals and departments, "Eurasia” fit the bill. While Sinor had defined his Central Eurasia as the area untouched by the advance of Chinese, Indian, Persian-Islamic, and Russo-European civilizations, this new Eurasia not only included Russia but was in fact centered on it. ${ }^{6}$ And while Sinor saw Central Eurasia as virtually disappearing in the modern era, eclipsed by the rise of Russia and China, the new Eurasia was very much a preserve of policy studies and contemporary politics.

\section{CENTRAL EURASIA: SOLUTION TO THE OLD PUZZLE?}

Just as the creation of the Royal Central Asian Society popularized the term "Central Asia," so the creation and naming of the Central Eurasian Studies Society (CESS) in 1999 posed anew the question, what is "Central Eurasia?" Is "Eurasia" here understood as the former Soviet empire, or is it "Central Eurasia" in Sinor's sense? Implicit is the claim that the vast area traditionally designated by terms like Tartary, Central Asia, Inner Asia, or Central Eurasia is a useful unit of analysis. But is there anything unifying such vast areas so that studying them together made sense? 
Adding to the confusion were the close linguistic, cultural, and religious links of Middle Asia with Turkey and Iran. From that perspective, any Central Eurasia that included Uzbekistan or Tajikistan had to include Iran and Turkey as well. Outside policymakers, too, often approached the former Soviet "-stans" as so many arenas for rivalries between different agendas in the Muslim world: the Sunni-style Salafist extremism of al-Qaeda, Iran's Islamic Republic model, or the secularism of Turkey. Thus it is not surprising that the "Perspectives" section of the Central Eurasian Studies Society's first issue of its journal, the Central Eurasian Studies Review, actively took up the question of What is Central Eurasia? For many of the writers in this section, Central Eurasia was effectively defined as the area where Russia, Islam, and Turks interact (Khidirbekughli 2004:4-5; Lehrman 2004:5-6).

The core of this Central Eurasia would be the four Turkic-speaking countries of Central Asia, the Volga and Crimean Tatars, and Azerbaijan. Less central, but still close enough, are those areas where two out of three can be found: Turks and Muslims but not Russians, as in Xinjiang and Turkey; or Russians and Muslims but not Turks, as in Tajikistan and Chechnya (Fig. 4.1). The outermost penumbra is formed of areas where only one of

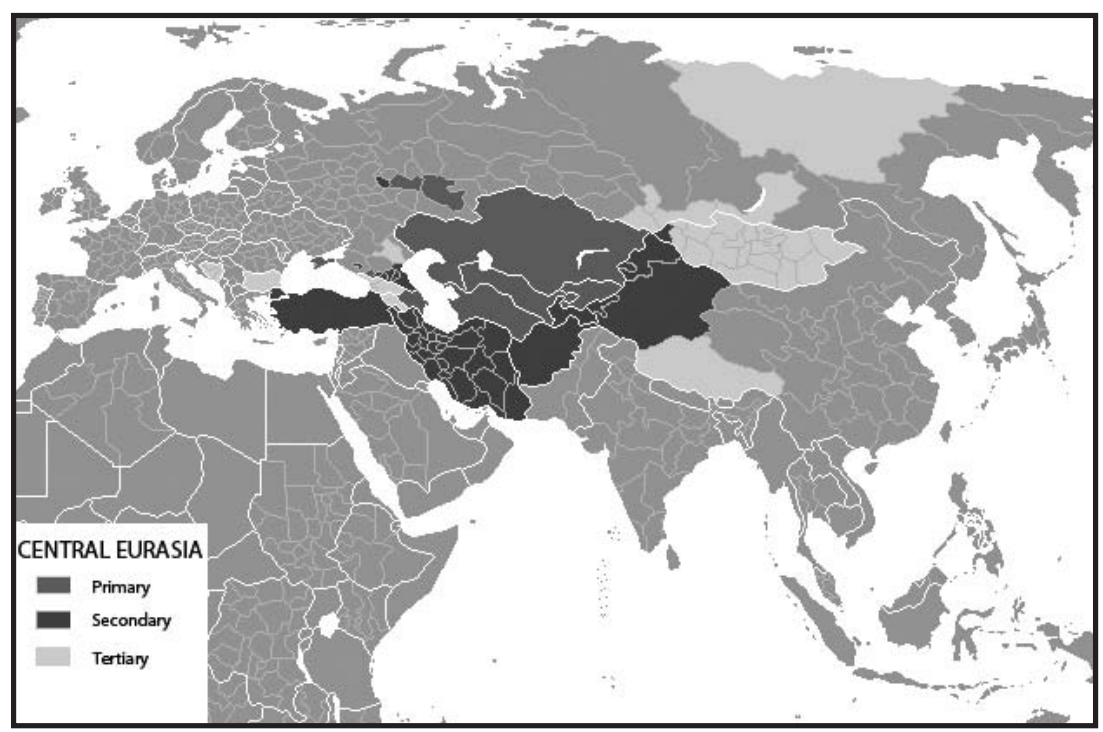

4.1. Mongolia and the "Central Eurasia" of the Central Eurasian Studies Society. 
these features is still predominant, but a more-or-less strong background from the others can be seen, as in Iran, Afghanistan, Georgia, and so on.

From the perspective of a historian of Mongolia, however, such definitions of Central Eurasia exclude Mongolia. Once the very heart of Tartary, and High or Central Asia, Mongolia is now the odd man out as it lacks Russians, Muslims, and Turks, having in their place Chinese, Buddhists, and Mongols. The principles of unity which have been advanced to explain what holds together Central Eurasia define Mongolia as some land beyond Central Eurasia's eastern periphery.

These new policy-oriented definitions of "Central Eurasia" developed at the expense of the older definition crystallized by Rene Grousset (1970), Denis Sinor (1970:93-119), and others, who defined their region of study (whether called "Central Eurasia," "Inner Asia," or simply "the steppes") by the ancient Altaic trinity of yurt nomads, Altaic languages, and native religions. The emphasis on native religions did not necessarily mean that Muslims or Buddhists were disqualified but that their Islam or Buddhism was preferably seen as nominal, or at most a superficial gloss on their shamanistic essence. ${ }^{7}$ Yet a strong case can be made that since the 14th century, the links unifying the Altaic nomads have gotten much weaker, and that the old idea of the steppe belt has little significance in modern society and culture.

The word "Mongol" is inextricably associated with Central Eurasian nomadism, not only because the Mongols are the largest modern population of yurt-nomads but also because of the Mongol world empire. Of all the Central Eurasian nomadic empires, this was the most powerful, the best documented, and the only one that included virtually all of Central Eurasia's nomads, from Southern Siberia and eastern Manchuria to Crimea and Turkey (Fig. 4.2). Despite the claim by some that its very size and rule over sedentary peoples make it atypical, it has consistently been the workshop where much of the most important research on classic nomadic polities is taking place. ${ }^{8}$ The Mongol Empire, as shown by Thomas Allsen's research, is also the apogee of the cross-civilizational interaction that many see as Central Eurasia’s primary contribution to world history (Allsen 1997, 2001, 2002).

Certainly the decline of yurt nomadism, which is now practiced in anything like the classical form only in Kyrgyzstan, northern Xinjiang, Tuva, independent Mongolia, and the adjacent border regions of Inner Mongolia, has cut a vital link that once brought together peoples from Manchuria to 


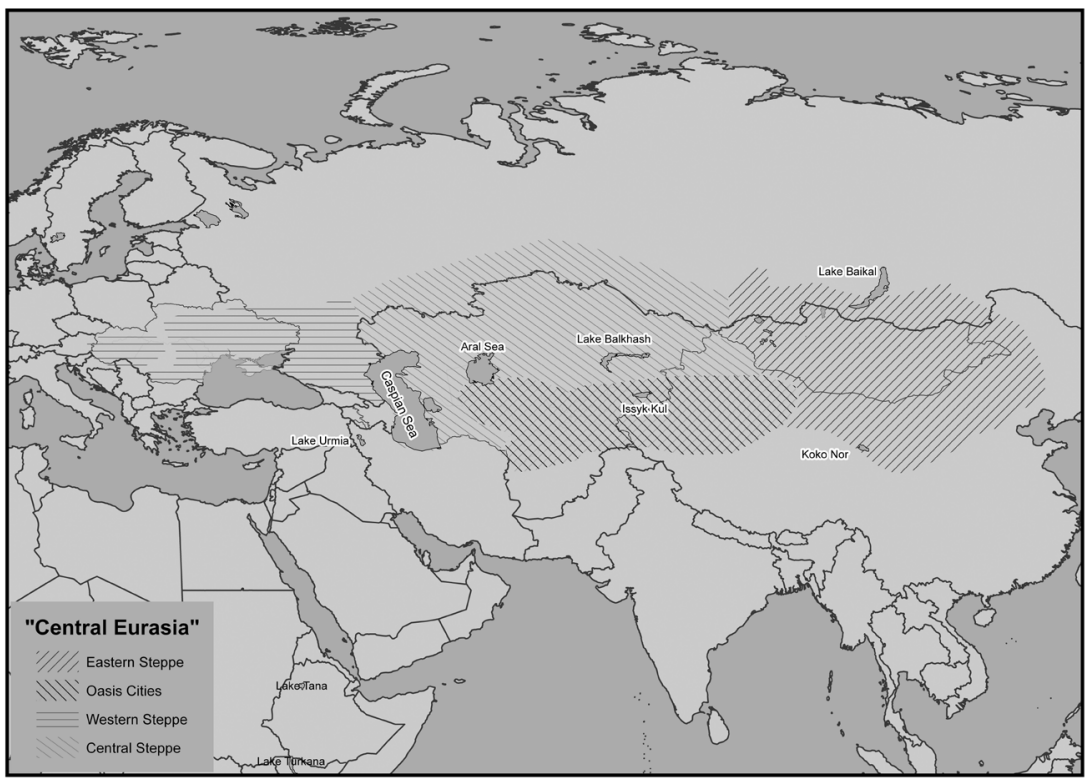

4.2. The Central Eurasia of archaeology and early to mid-medieval history.

Hungary. ${ }^{9}$ Meanwhile the links between the Altaic languages, ongoing and powerful in the period from the 2 nd century BCE to the 14 th century CE, have weakened. Intra-Altaic circulation of loan words has effectively ceased, and with few exceptions Altaic languages are currently under far more powerful influences from non-Altaic languages than they are from other Altaic languages (Comrie 1981:64-65, 84-85).

Likewise, Central Eurasia’s significance as a bridge between civilizations declined precisely as a result of its incorporation into neighboring civilizations. Because nomadic empires were not strongly associated with one or another world religion or civilization, they often forcefully promoted cultural interchange between two regions, East Asia and the Middle East, which were often not very welcoming to such exchange. Chances for this kind of exchange withered when the nomads themselves became participants in the world religions and reoriented their movements not to trade routes between civilizations but to pilgrimage routes into the heart of the great civilizations (Fig. 4.3). 


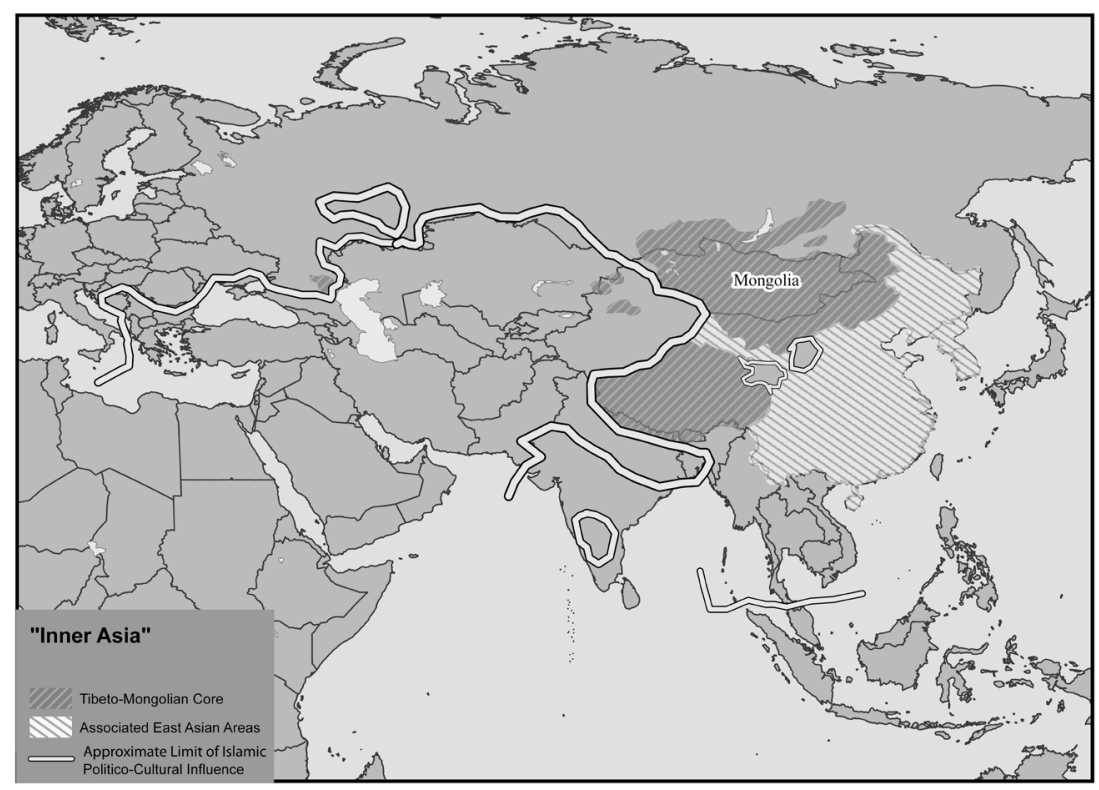

4.3. The Inner Asia of the Buddhist oikumene, 1260-1900.

\section{MODERN GEOPOLITICS}

In the 20th century, recurring patterns of crisis in the Russian and Chinese empires have helped define an area of instability situated between the two. The existence of regional majorities of non-Russian and non-Han Chinese populations, together with the ascription of "nationality" status to the territories implicit in the two empires' "autonomy" policies has marked this zone of instability as also a zone of ethnic politics. In the modern geopolitical definition, Central Eurasia is thus parallel to the old definition of Central (or Eastern, or East Central) Europe: a land of small and weak nationalities situated between two powerful politico-economic-cultural-demographic juggernauts, Germany and Russia (Fig. 4.4).

In the 18th and 19th centuries, countries in Asia had to acquire a modicum of modernization if they wished to avoid colonization and subsequent swamping by colonial settlers. But the countries of Central Eurasia were unable to do so because of their landlocked position, which impeded communications and reduced their options for independent contact with nonthreatening foreign advisers. They were also held back by the comparative 


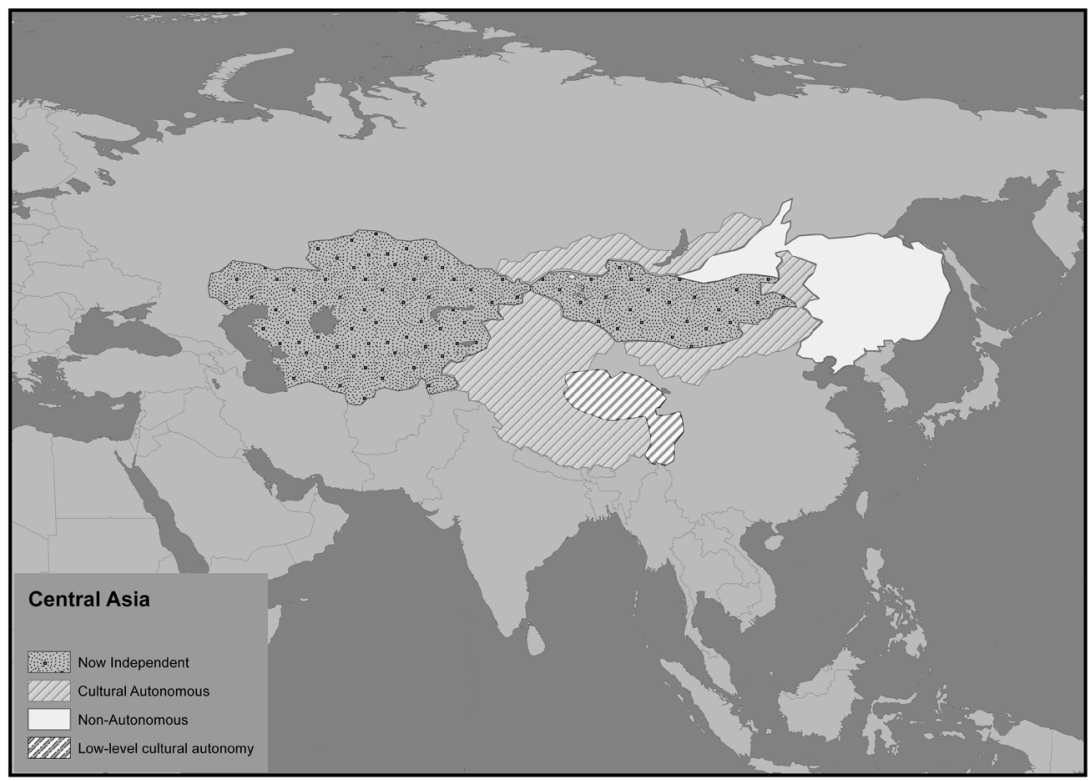

4.4. Central Asia of Sino-Soviet geopolitical competition and minority issues.

weakness and underdevelopment of the colonizing powers, Russia and China. Finally, while countries like India or Indonesia could easily absorb any number of colonial settlers, even small bodies of Russian or Chinese had outsized impact in Central Eurasia, with its sparse population. Even today, many of these same issues pertain. Central Eurasia's indigenous nations not only have no "nukes," they do not even have any plausible nuclear ambitions (see Enkhsaikhan's chapter, this volume).

In this definition, the Mongolian Plateau certainly fits into "Central Eurasia," having been like Poland alternately within one empire, then the next, and then partitioned between the two. Mongolia is unusual only in the current absence of a significant remnant colonial settler population. Xinjiang and Tibet, areas with significant secessionist movements that have forced their activities onto the world's news agenda, also fit in this geopolitical Central Eurasia. Inner Mongolia springs less readily to mind as its secessionist movement and presence on the world's agenda is so much weaker. ${ }^{10}$ Still, to the degree that those areas where ethnic Mongols remain an important part of the population still exist, Inner Mongolia, too, is definitely part of this geopolitical Central Eurasia. 
Even in geopolitics, however, many observers promote unifying concepts that have no relevance to Mongolia. If the issues defining Central Eurasia are radical Islam, terrorism, or pipelines, then Mongolia is not part of Central Eurasia, although the country does have significant oil reserves. But the last few years have demonstrated that while new actors such as the United States, the European Union, Japan, South Korea, and international organizations certainly have important roles to play, the countries with long-term staying geopolitical power in Central Eurasia are still Russia and China. How much time depth does this conception of Central Eurasia actually have? Before the 17th century, Russia was a minor player in the steppe. This is only one example of the limitations of the proposed unifying concepts for Central Eurasia: the limits of Russia, the limits of Islam, and the limits of Turks.

\section{The Limits of Russia}

The Russian expansion into inland Eurasia was eventually checked by the Manchu Qing (Ch'ing, 1636-1912) Dynasty, an empire which, while not ethnically Chinese, was certainly pervasively influenced by Chinese language and culture. Mongolia proper and Inner Mongolia, Tuva, and Xinjiang were thus all kept out of the Russian sphere of influence until the decline of the empire after its defeat by Japan in 1895 .

With the fall of the Qing Empire, only Tuva and Mongolia proper (Outer Mongolia) were stripped permanently from the succeeding Republic of China. Fearing possible Russian infiltration, British India established a protectorate over Tibet, but Xinjiang came under strong Russian influence, to the extent that Stalin's purges were extended into the region under the rule of the Chinese general Sheng Shicai. ${ }^{11}$ Russian language training of Xinjiang's elites was also widespread. It should be kept in mind, however, that Xinjiang's primary administrative language since about 1875 has been Chinese and that Russian sources have importance in its history only as those of a powerful foreign patron (comparable, for example, to that of the United States in South Korea), not as those of the administering colonial power.

More surprising is the real limit of Russophone influence on Mongolia. Up to 1911, Mongolia was part of the Qing Empire and few Mongolians had close contact with Russians. The imposition of a Soviet-style government on Mongolia was a tortuous process, beginning in 1921 but not completed 
until 1940. Even after World War II, a significant Russian settler population did not develop; Russian was never used as an official administrative language; and Mongolian remained the main language of higher education. This is not to argue that Soviet Russian culture did not have a powerful impact on Mongolia but simply to note that despite the adoption of the Cyrillic script by 1950 and talk in the Cold War era of Mongolia as the Soviet Union's sixteenth republic, Russian influence was qualitatively less pervasive than in Central Asia.

This history is reflected in present-day social interactions. To take a simple example near home, the Central Asian and Russian communities developing around Indiana University are closely connected, but the Mongolian community interacts very little with either. Since 1990, the switch to English as the main foreign language in general education has been rapid, and the Mongolian government is now committed to the probably unrealistic goal of making Mongolia bilingual in English and Mongolian (Brooke 2005). While a number of persons are concerned about the rapid loss of Russian abilities, particularly since fluency in either English or any other non-Mongolian language does not seem to be taking its place, still the movement of Mongolia out of the Russian linguistic orbit is undeniable.

This linguistic movement can be illustrated well in the world of scholarship. In 1982, 79 percent of the Mongolian scholars at the flagship International Congress of Mongolists chose to give their papers in Russian. Ten years later only 2 percent did, and 94 percent spoke in Mongolian (see Table 4.1). English, however poor, is now used as much or more by Mongolian academics than Russian. The Russophone identity of Mongolia thus emerges not as a continuing and defining condition as it is in the Central Asian republics but only as a temporary phase, lasting from 1930 to 1990. Indeed, it is curious that even at the first international Congress of Mongolists in 1959, 88 percent of the Mongolian participants chose to speak in Mongolian. As far as Mongolist congresses go, the Russophone period of Mongolian scholarship really lasted two decades at most.

\section{The Limits of Islam}

The limits of Islam in inland Eurasia have generally been very sharp. It is striking how almost every community in the area has maintained the religious choices it made in the breakup of the Mongol Empire (1300 to 1400). The Turco-Mongol peoples of the former Golden Horde and the 
Table 4.1. Proportions of Mongolian Scholars Giving Papers in Mongolian, Russian, and English at the International Congresses of Mongolists in Ulaanbaatar

\begin{tabular}{llll} 
YEAR/TOTAL & & & \\
MONGOLIAN & PRESENTING IN & PRESENTING IN & PRESENTING IN \\
PARTICIPANTS & MONGOLIAN & RUSSIAN & ENGLISH \\
1959:16 & $88 \%$ & $13 \%$ & - \\
$1970: 45$ & $7 \%$ & $69 \%$ & $24 \%$ \\
$1976: 63$ & $29 \%$ & $65 \%$ & $6 \%$ \\
$1982: 72$ & $21 \%$ & $79 \%$ & - \\
$1992: 42$ & $93 \%$ & $2 \%$ & $5 \%$ \\
$1997: 80$ & $94 \%$ & - & $6 \%$ \\
$2002: 94$ & $95 \%$ & - & $5 \%$ \\
\hline
\end{tabular}

Sources: Tsoloo (1961-62); Shirendew (1973, 1977-79); Bira (1985-86); Mongolica 1994-96(5-7): 26-28; 1999-2002(9-12): 30-33; 2003-06(13-14): 34-38.

Chaghatay Khanate chose Islam, while the Turco-Mongol peoples of the Yuan Dynasty chose either Tibetan-rite Buddhism or remained with their Altaic native religion. ${ }^{12}$ The only exception to this continuity seems to be the conversion of the Uighurs of Besh-Baligh, Turpan, and Qumul to Islam in the early 15 th century. ${ }^{13}$

It is often claimed that the influence of Buddhism on the Mongols before 1581 was superficial and restricted to the court. Recent archaeological discoveries have cast doubt on this contention by documenting, for example, the widespread depiction of Buddhist rosaries on Yuan-era seated funerary statues in southeastern Mongolia and central Inner Mongolia, and the occurrence of the Sanksrit syllable om on funerary bowls in Yuan tombs in northeast Mongolia and Trans-Baikalia (Bayar 2002:125-28, 177; Bayar 2000:17; Tümen 2006). Nor did Buddhism disappear in post-1368 Mongolia. There is direct documentation of continuous adherence to Buddhism among the large Mongol community in Beijing as well as among the Mongolophone and Turcophone populations in Kökenuur (Kara 2005:69-71, 143; Heissig 1980:25-26; Sperling 1992:741-50). Moreover, on the Mongolian Plateau, Esen Taishi appointed a Tibetan Buddhist guoshi (state preceptor) in the mid-15th century. Lubsang-Danzin's Altan tobchi records the presence of both a bagshi (Buddhist teacher) and a jaarin (shaman) at the court of Dayan Khan (1480?-1517?), the great restorer of Mongol unity (see Jagchid 1988:121-27; Bira 1990:165). Indirect evidence is just as important: 
the preservation of 14th-century colophons and pre-classical features in the 17th to 18th century Mongolian versions of famous Indo-Tibetan Buddhist texts, such as the Golden Beam sutra, the Twelve Deeds of the Buddha, the Pancaraksha, Shantideva's Bodhicaryavatara, and Sa-skya Pandita's Treasury of Aphoristic Jewels necessarily imply continuous copying of these texts through Mongolia's "Dark Ages." ${ }^{14}$ In two texts recently recovered from the Qasar shrine in Inner Mongolia and dating from before 1581, the Chinggis Khaghan-u altan tobchi and the Chinggis Khaghan-u takil-un sudur oroshiba, we find both Buddhist mythological elements such as the Shala tree, the wishing-jewel, the idea of Indra as the lord of the gods and so on, as well as Buddhist invocatory formulas (Dorungg-a 1998:98-100, 166; Chiodo 1989/91:202; Chiodo 1992:87). Thus while Mongolian practice in the period 1368 to 1581 certainly fell far short of the exacting standards of Gelugba (dGe-lugs-pa) Buddhist orthodoxy that prevailed afterwards, the Mongols' cultural vocabulary and communal identity remained, however tenuously, Buddhist.

Since the breakup of the Mongol Empire, Muslim nomads such as the Kazakhs, Nogay, Bashkirs, and Kyrgyz have fought against and competed for pasture with the Oirat (Kalmyk or West Mongolian) Buddhist nomads along a series of fronts from the Don to the Altai to the Tsaidam Basin in northern Tibet. ${ }^{15}$ While fortunes have seesawed in this conflict, no players have switched sides for centuries. A striking illustration of the importance of history in this conflict has been how the southern Siberian Turks (Yenisey Kyrgyz and Tuvans), even when not Buddhist, have generally integrated easily into Mongolian Buddhist societies; evidently a common history in the Yuan and Qing dynasties and the resulting common cultural vocabulary have proven more important than language. ${ }^{16}$ The strong similarity between Mongolian and south Siberian Turkic heroic fairy tales, linked to shamanic and hunting magic, as opposed to the more conventionally heroic epic of the Central Asian Turks also underlines this point. ${ }^{17}$

The contrasting religious affiliations resulted in differing human and intellectual ties. In many ways, Tibet and to a lesser degree China came to fulfill the same role toward Mongolia that Iran and the Arab world did toward the Central Asian Turkic world. Mongol pilgrims kowtowed their way south and east to Wutai Shan and Beijing in China and to Gümbüm (sKu'bum), Labrang (bLa-brang), and the famous "Three Seats" of Lhasa, while Muslims were and are drawn, of course, to Mecca as well as to local and 
Middle Eastern saints' tombs. Stories and narratives differ as well: for centuries Mongols were raised on chadig (jataka) tales of the Buddha's previous lives, the life of Milaraiba (Mi-la-ras-pa, the famous Tibetan yogin), as well as a distinctive 15th-16th century apocryphal story cycle of Chinggis Khan that, as noted above, contains important elements of Buddhist cosmology. In the 19th century, Chinese novels, particularly those with a Buddhist theme such as Journey to the West, became great sources of entertainment (Atwood 1992/93). In contrast, Turkic Muslim literature was formed by the legends of the Prophet Muhammad and 'Ali, by the romances of Layla and Majnun and Abolqasem Ferdowsi's Shahnameh, and the tradition of Arabic and Persian poetry (Szuppe 2004).

The Buddhist world was probably not as united as the Islamic world. The fact that Mongols, Tibetans, and Chinese each had unrelated scripts while all Islamic peoples switched to the Arabic script is a sign of the greater diversity and lesser degree of cultural solidarity within the Buddhist oikumene (cultural world). Still, Johan Elverskog has demonstrated how Qing Dynasty Mongols in the 19th century saw themselves as forming (together with the Tibetans, Chinese, and their Manchu rulers) a single Buddhist commonwealth, facing challenges from both Hui and Turkestani rebels as well as Catholic missionaries (Elverskog 2006:139-46). Just as Turkestanis in China interpreted the 1864 revolt religiously as, in the words of the main Chaghatay Turkic history of the conflict, "Holy War in China" (ghazât dar mulk-i Chîn), so, too, the Oirats of Xinjiang made common cause with Chinese miners and Manchu soldiers in fighting the Turkestanis (Kim 2004:66-71, cf. 56-57, 94). ${ }^{18}$ This action was informed by the legacy of the 11th century Buddhist Kalachakra Tantra, which pinned its hope for a spiritual and military response to Islam on the hidden kingdom of Shambhala (Newman 1998). This common Buddhist oikumene was only shattered in the turn of the 20th century, first by the Qing Dynasty's turn to secular reformism in the New Policies of 1901 and then by Mongolian and Tibetan nationalist readings of history, which played up anti-Chinese and anti-Manchu sentiments (see Atwood 2002:35-55).

Today an important revival of Buddhism is occurring in Mongolia. While there was only 1 monastery and 100 monks in 1990, by 2003, there were nearly 200 restored monasteries and about 3,000 monks. Just as important, if not more, for the purposes of this paper is the renewed identification of the Mongolian national community and state with Buddhism. 
Buddhist mythological symbols and concepts such as the "wind horse," the "wishing jewel," and the "three times" were added to Mongolia's state emblems in the new constitution in 1992 and are identified as "symbols of the independence and sovereignty of Mongolia” (Kollmar-Paulenz 2003).

\section{The Limits of Turks}

While the earliest monuments of Old Turkish language are famously found in the heartland of modern Mongolia, Mongolian speakers began expanding at the expense of Turks in the 10th century (Golden 1992:18387, 283-87). This expansion jumped all bounds when the Mongol Empire planted Mongolian-speaking communities as far as Kayseri, Kandahar, and Kiev. Although the fall of the empire brought the assimilation of the more far-flung Mongol communities into the indigenous populations, it did not halt the more gradual westward expansion of Mongolian language on the Mongol Plateau. (It should not be forgotten that numerous descendants of the Mongols in Afghanistan and Moghulistan remained Mongolian-speaking well into the 16th century.) The pre-Chinggisid Turkic-speaking Naiman tribe straddling the Altai appears to have moved into modern Kazakhstan by 1415 , to be replaced on both sides of the Altai by the Mongolian-speaking Oirats. The Önggüds or White Tatars, Christian Turco-Sogdians of Inner Mongolia, were fully assimilated into the Buddhist Mongolian culture by the 16th century. Indeed, the father of the famous Mandukhai Sechen Khatun (Wise Empress Mandukhai), cofounder of the great Chinggisid revival of the 16th century, was an Önggüd. The expansion of the Oirats (including Kalmyks) reached its height in the 17 th to 18 th centuries. But after 1750 , the Oirats, crushed by Russian and Qing power, retreated in the face of a Tibetan resurgence in Qinghai, a Kazakh resurgence in the Altai, and a Russian and Turkic resurgence in the Pontic-Caspian steppe. From 1750 to 1850, the Volga Kalmyks, the Xinjiang Oirats, and Kökenuur's “Upper Mongols" all suffered repeated devastating attacks from their former subjects.

This fault line in spoken language between Mongolic and Turkic was much widened by the breakdown in Turco-Mongolian symbiosis in the wake of the Mongol Empire. The Empire's ruling class was bilingual in Middle Turkish and Middle Mongolian, using Turkish to communicate with their subjects in the west and communicating directly in Mongolian with the Chinese, Tibetans, and Koreans. Uighur scribes, whether Christian or Buddhist, shared a script, a calendar, and a considerable terminology of civilization 
with their Mongol employers (Allsen 1983). Despite Tibetanization, significant elements of this terminology and practice were preserved in Mongolian versions up to the 20th century. In fact, it is the Mongols, not the Muslim Uighurs of today, who inherited most of the Central Asian Buddhist terminology used in the Uighur oasis kingdom (Kara 2000; Shogaito 1991).

The fall of the Mongol Empire and Islamization in the west broke up this synthesis. Despite the Timurid renaissance of the vertical Uighur script, Islamization meant the replacement of the Uighur script with the Arabic script. Although the twelve-animal cycle was still used and Chinggis Khan's jasaq or law code often invoked by Muslim descendants of the Mongols, new calendars, new food, and new daily customs widened the breach between Muslim Turks and Buddhist Mongols. ${ }^{19}$ Already in the Ilkhanate, the advent of the Islamic practice of endogamous marriages (marriages within the patriclan) had shocked many Mongols and their Uighur officials raised in the universal East Asian code of exogamy. ${ }^{20}$ Oasis merchants from Turpan, Qumul, Samarqand, and Bukhara continued to trade in Mongolian animal products both internally and into China and Russia. But the Buddhist-Muslim religious divide meant that cosmopolitan clerics, scribes, and bankers from these oasis cities no longer served as tutors, scribes, judges, and advisers for the postimperial Mongol khans the way the Uighurs had. For the now Muslim Uighurs, vocabulary from Persian and Arabic replaced the Sanskrit-Chinese-Mongolian vocabulary of the old Buddhist Uighur scribal language.

On the other hand, the revival of Mongolian monastic Buddhism in the late 16th century gave the Mongols a wholly new and native source of clerical talent, one committed to a complete rejection of any coexistence with the Turkic Muslim or Russian Christian buruu nomtan ("ones with the wrong religion," i.e., infidels). This change can be seen clearly in personal names among the Oirats. Around 1500, they were still virtually illiterate and had undergone little influence from the mainstream Mongolian written culture. In this situation, in genealogies we find numerous Turkish names (e.g., Bay-Baghish, Aq-saqal, Eselbay, Yanis) and even titles (e.g., sultan, mirza) testifying to an Oirat-Turkic symbiosis. By 1650, however, with the Buddhist conversion, the creation of new monastic communities, and the popularization of the new Oirat Clear Script, such Turkic names and titles had completely disappeared to be replaced by Tibetan names and Mongolian titles, most drawn ultimately from Chinese. ${ }^{21}$ 


\section{CONCLUSION}

So is Mongolia part of Central Eurasia? The answer, not surprisingly, depends on how, and even more when, we define Central Eurasia. In the "ancient" or "classical" world of pagan steppe nomads that lasted up until the 14th century, Mongolia is not just part, but perhaps the very heart, of Central Eurasia. In the "modern" world of geopolitics, colonization, and science, Mongolia is also part of Central Eurasia, dealing with the same issues: formation of a premodern aristocratic ethnie into a modern egalitarian nation ${ }^{22}$; competition of established religion, reformist movements, and radical secularism; geopolitical competition between Russia and other powers, especially China; conflicts between nomads and advancing farmers of outside nationalities; and the long path of securing independence and an international personality apart from the imperial powers. Yet in this modern Central Eurasia, Mongolia remains something of the odd man out: Buddhist, not Muslim; comfortable with secularism, not anxiously eying religious opposition; democratic, not autocratic; fearing neglect from the Western democracies more than self-interested intervention; and exporting cashmere and copper, not cotton and natural gas.

It is in the "medieval" world of religious states, pilgrimages, and hagiographical literature that Mongolia and much of the rest of Central Eurasia part ways. In these "middle ages," lasting from the 14th century through the 19th, Central Eurasia appears not as one region but as two peripheries of two different worlds-one looking to Istanbul and Mecca and the other to Lhasa, Wutai Shan, and Beijing and beyond to Bodhgaya. One can compare this sundering of an ancient unity to the partition of the Mediterranean world (which was clearly a unity in the Hellenistic, Roman, and Late Antique periods) into the rival Christian and Islamic worlds in the Middle Ages. Yet those like Ferdinand Braudel who have striven to rescue the continuing economic and social unity of the Mediterranean from religious and intellectual division have scored significant intellectual successes. Their example shows us the fruitful possibilities for research into both continuing economic and social ties between Buddhist and Islamic Central Eurasia and a comparative intellectual and social anthropological history that treats how these separate entities handled the "classical" legacy of Altaic nomadism and Chinggis Khan.

Is Mongolia part of a unified Central Eurasia? The answer is definitely "yes" for the "ancient" historian (up through the breakup of the Mongol 
Empire), pretty much "no" for the "medieval" historian (from the 14th century to the 19th), and a qualified "yes" for the "modern" historian. Political scientists, transition economists, students of international relations, and journalists are already fruitfully looking at Central Eurasia as a whole. Archaeologists already consider Central Eurasia a real unity, annoyingly broken along modern lines by the language difficulties of a field divided between Russian, Mongolian, and Chinese research languages. Specialists in shamanism, the material culture of nomadism, music, and oral literature will find variable amounts of common ground, although many of the links between Mongolian and Siberian Turkic cultures-often interpreted as ancient Altaic motifs - may well be the result of continuing "medieval" (i.e., post-Mongol empire) connections. However, specialists in world religions, literature, arts, and architecture will find that Mongolia and Uzbekistan, for example, function more as possible areas of parallel comparative research (like comparing European and Japanese feudalism or medieval Christian and Islamic philosophy) rather than as a single field.

Mongolia's position vis-à-vis "Central Eurasia" can be well conceptualized with the thematic idea of "-scapes," as Paula Sabloff discusses (see Chapter 2). Archaeologists, religious studies scholars, folklorists, sociocultural anthropologists, historians, and political scientists (not to speak of politicians!) all inhabit different "-scapes," with Mongolia situated in different locations in each. The significance of these alternate "-scapes" is particularly obvious when we map pilgrimages (both literal and metaphorical) that people in Mongolia, Kazakhstan, or Xinjiang, for example, make in pursuit of religious merit, higher education, or economic opportunity. ${ }^{23}$ Suddenly the unified Central/Inner Eur/Asia fractures into patterns of travel and affiliation, patterns that differ for each community and within each community; these patterns can be mapped. Each of these "-scapes" is oriented to a different focal point of religious, economic, or intellectual capital, but these focal points are frequently situated entirely outside of Central Eurasia, whether it be in Mecca for Kazakh hajjis, in Beijing Uighur students, or in the United States Mongolian emigrants.

Yet the "-scapes" are unified by the fact that one person feels multiple "-scapes" operating in his or her life. A Mongolian accountant working in Washington, D.C., may retain a vivid sense of the Dalai Lama as a locus of religious merit, the steppes of Mongolia as an idealized natural environment, and above all of "Mongolian-ness"—rooted in language, history, and 
race-as a vital part of her identity. All these may coexist with her "-scape" formed by nostalgic memories of student days in Moscow and her present "-scape" formed by American economic and political power. Mutatis mutandis, the same is true for other peoples of Central Eurasia. Some "-scapes" are seen as more intrinsically important and worthy of celebration than others, even if they do not seem to motivate action; those "-scapes" are usually the ones defined by language, religion, putative common ancestry, or history. It is exactly these historically rooted "-scapes," variable and multiple as they are, that form the basis for area studies. To this extent, then, it is outdated and unfashionable area studies that ironically speaks to those "-scapes" that are often seen as most crucial by nonacademics.

This is the future of area studies and why it will have to continue to negotiate a difficult passage between two poles. For those engaged in academic study, the lines of classification merely facilitate research and fruitful intellectual exchange, just as with historical periodization. But for those, often the same person, with an emotional investment in concepts of religious, linguistic, or national unity, the creation of broad areas becomes an important statement about self. Placing Mongolia on the map is an important task, because it helps shape how we, Mongols and non-Mongols alike, place the country and people in different Mongolian "-scapes." The academic will insist on being aware of the history of such classifications and how this history has reflected different moments in the history of Mongolia and the Mongols. Those with identities bound up in Mongolia, however, will naturally see something much more important in these classifications and find their endless constructions and reconstructions to be more than an intellectual game. As long as we recognize the difference between these two approaches, area studies can be an important site for intercultural and international learning and reflection.

\section{NOTES}

1. See the Oxford English Dictionary/OED Online, s.v. "Near East"; "Middle East"; "Far East."

2. OED Online, s.v. "Tartary" citations range from 1369 to 1891, although books with Tartary in the title were published with only a light touch of deliberate archaism into the 1930s, e.g., Lattimore 1930 and Fleming 1936.

3. There is no entry for "High Asia" in the OED Online, but it is found under "Ugro-," (1848), "Lepcha" (1862), "high" (1869), and "Balti” (1899).

4. There is no entry for "Central Asia" in the OED Online, but a citation from 1850 is found under "Altaic." 
5. See Sinor (1954:82-103). In the second edition of the same work (Sinor 1970: 93-119) and in virtually all of his writings, however, he used the term Inner Asia for this entity, due to its greater currency at the time. Yet that he assigned to this term the same meaning as his own coinage "Central Eurasia" is demonstrated by the integral inclusion of Scythians, Huns, Avars, Khazars, Magyars, and other peoples west of the Urals in Sinor 1990.

6. A witty and provocative look at the new "Eurasia" is in Kotkin (2007:487-531).

7. This idea is, however, effectively refuted in DeWeese (1994) and Privratsky (2001). For arguments in a similar vein with regard to Mongolia, see Atwood (1996).

8. Barfield (1989) has argued strongly that the Mongol Empire is not a typical steppe empire. Despite this (I believe on many points very cogent) argument, any discussion of nomad polities is still likely to give pride of place to the empire of Chinggis Khan. It may not be the most typical nomadic empire, but it is the most important and best documented one.

9. The latest example is the policies in Inner Mongolia first of fencing pasture and then of shengtai yimin, or "ecological migration," undertaken to move herders off the steppe to relieve overgrazing. This policy is eliminating nomadism and indeed much of Inner Mongolia's steppe population rather rapidly (Williams 2002). The contemporary issue of "ecological migration" has not attracted significant attention outside the Inner Mongolian emigré community. See, however, Dickinson and Weber (2007).

10. On Inner Mongolian dissidence, see Togochog 2002. On modern politics in Inner Mongolia, see Bulag 2002 and 2004.

11. Ironically after Sheng Shicai's turn to the Kuomintang in 1942, the terrible legacy of the Stalinist purges in Xinjiang was publicized by his Soviet-supported enemies as evidence of his "fascism."

12. Like DeWeese, I prefer the term "native religion" to the misleading "shamanism" as a description of the pre-Islamic, pre-Buddhist, pre-Christian religion of the peoples of northern Asia.

13. On the history of the Uighurs (in the narrow sense) after the fall of the Yuan Empire, see $\operatorname{Kim}$ (1999:290-318) and Oda Juten (1978:22-45).

14. See the survey of the evidence in Ligeti (1973:5-10) and the examples in Kara (2005:4647, 274).

15. On Zünghar and Kalmyk views of Islam see Atwood (2006:231-237). On Kazakh and Kyrgyz views of the Oirats, see Hatto (1989).

16. This can be seen vividly in Louisa Waugh (2003). As an English teacher in Mongolia's far western Tsengel sum (county), she found that Mongols and Tuvans formed a single social network of friends and marriage relatives. But it was almost impossible for her to straddle the social divide between the Mongol-Tuvan society on one side and the Kazakhs on the other. In Xinjiang, the small number of Turkic-speaking Tuvans have been included as part of the Mongol nationality and not with the Kazakhs who form the local majority (Mawkhanuli 2005).

17. Although Nora Chadwick and Victor Zhirmunsky disagree as to whether they are more properly "nonheroic epics" or "heroic folktales," both discern a Siberian Turkic type of narrative poetry that is quite different from the Central Asian types and much closer to Mongolian forms (Chadwick and Zhirmunsky 1969:78, 104, 106, 174, 180, 312ff.). Hatto (1993:269-78), in a comparative look at Mongolian and Kyrgyz epics, concurs with Heissig's description of Mongolian "epics" as "heroic folktales" 
(Heldenmärchen) that, while sharing a number of motifs with Kyrgyz epics, stand out by imperviousness to history, their link to exorcistic religion, their "sense of black and white" in their heroes and monsters, and a "robust appetite for grotesques."

18. See also Yang 2001, who contrasts the Mongol view of the Hui (Chinese-speaking Mus$\mathrm{lim}$ ) insurgents of Gansu as cruel, if sometimes courageous bandits first with the current Chinese official view of them as popular rebels against the Qing dynasty's "semi-colonial, semi-feudal" regime and then with a Hui author's view of them as Sufi martyrs.

19. Insightful studies of the Chinggisid legacy in the Islamic successor states of the Mongol empire include Sela 2003, Aigle 2004a and 2004b, and Subtelny 2007.

20. See, for example, Morgan (1986:162-63). Morgan does not understand that the Mongol noble Qutlugh-Shah's outraged contention that Islam permits marriage to one's daughter or mother or sister is the common East Asian response to any marriages within the patriclan. In the Mongol (and Hindu, Tibetan, and Chinese) view, one's father's brother's daughter, a preferred partner according to Islamic law and custom, is for marital purposes quite equivalent to a sister, while patrilateral cousins in the descending generation or ascending generation are like nieces or aunts. The author of the Indian Buddhist text, the Kâlacakra tantra, written between 1025 and 1040 CE, made the same point (Newman 1998:319, 328).

21. This change may be verified by examining the genealogies of the Oirat nobles in, for example, Ghabang Sharab's "History of the Four Oirats," as found in Badai, Altan'orgil, and Erdeni (1985:234-39) or in Tsoloo (1967:74-78), or else the later Qing genealogies of the Iledkel Shastir conveniently resumed in Namsarai (1984).

22. On the concept of ethnie, see Anthony D. Smith's modern classic The Ethnic Origins of Nations (1986).

23. The concept of "pilgrimage" as covering not just religious movements, but movements in search of educational, economic, or status advancement comes from Benedict Anderson (1991).

\section{REFERENCES}

Aigle, Denise. 2004a. Le grand jasaq de Gengis-Khan, l'empire, la culture mongole et la shari'a. Journal of the Economic and Social History of the Orient 47(1): 32-79.

2004b. Loi mongole vs. loi islamique: Entre mythe et réalité. Annales: Histoire, Science Sociales 59(5-6): 971-96.

Allsen, Thomas T. 1983. The Yüan Dynasty and the Uighurs of Turfan in the 13th Century. In China among Equals: The Middle Kingdom and Its Neighbors, 10th-14th Centuries, ed. Morris Rossabi, pp. 243-80. Berkeley: University of Californian Press.

1997. Commodity and Exchange in the Mongol Empire: A Cultural History of Islamic Textiles. Cambridge: Cambridge University Press.

2001. Culture and Conquest in Mongol Eurasia. Cambridge: Cambridge University Press.

2002. Technician Transfers in the Mongolian Empire. Central Eurasian Studies

Lectures No. 2. Bloomington: Indiana University. 
Anderson, Benedict. 1991. Imagined Communities: Reflections on the Origin and Spread of Nationalism. London: Verso.

Atwood, Christopher P. 1996. Buddhism and Popular Ritual in Mongolian Religion: A Reexamination of the Fire Cult. History of Religions 36(2): 112-39. 1992/93. The Marvellous Lama in Mongolia: The Phenomenology of a Cultural Borrowing. Acta Orientalia Academiae Scientiarum Hungaricae 46:3-30.

2002. Young Mongols and Vigilantes in Inner Mongolia's Interregnum Decades, 1911-1931. 2 vols. Leiden: Brill.

2006. Titles, Appanages, Marriages, and Officials: A Comparison of Political Forms in the Zünghar and Thirteenth Century Mongol Empires. In Imperial Statecraft: Political Forms and Techniques of Governance in Inner Asia, Sixth-Twentieth Centuries, ed. David Sneath, pp. 207-42. Bellingham, WA: Western Washington University.

Badai, Altan'orgil, and Erdeni. 1985. Oyirad-un teüken surbulji bicig. Höhhot: Inner Mongolia People's Press.

Barfield, Thomas J. 1989. Perilous Frontier: Nomadic Empires and China, 221 BC to $A D$ 1757. Cambridge: Basil Blackwell.

Bayar, Dowdoin. 2000. Altan urgiin yazguurtny negen bulshiig sudalsan ni. Ulaanbaatar.

— 2002. Mongolchuudyn chuluun khörög: XIII-XIV zuun. Ulaanbaatar: ORBIS.

Bira, Sh., ed. 1985-86. Olon ulsyn mongolch erdemtnii IV ikh khural. 3 vols. Ulaanbaatar: Academy of Sciences.

—_ ed. 1990. Ertnii khaadyn ündeslesen tör yosny zokhiolog towchlon khuraasan Altan towch khemeekh orshwoi. Ulaanbaatar: State Publishing House.

Brooke, James. 2005. For Mongolians E is for English and F is for Future. New York Times, February 15:A7.

Bulag, Uradyn E. 2002. The Mongols at China's Edge: History and the Politics of National Unity. Lanham, MD: Rowman and Littlefield.

- 2004. Dialectics of Colonization and Ethnicity Building. In Governing China's Multiethnic Frontiers, ed. Morris Rossabi, pp. 84-116. Seattle: University of Washington Press.

Chadwick, Nora K., and Victor Zhirmunsky. 1969. Oral Epics of Central Asia. Cambridge: Cambridge University Press.

Chiodo, Elisabetta. 1989-91. "The Book of the Offerings to the Holy Činggis Qayan”: A Mongol Ritual Text. Zentralasiatische Studien 22:190-220.

— 1992. "The Book of the Offerings to the Holy Činggis Qayan”: A Mongol Ritual Text (Part II). Zentralasiatische Studien 23:84-144.

Comrie, Bernard. 1981. Languages of the Soviet Union. Cambridge: Cambridge University Press.

DeWeese, Devin. 1994. Islamization and the Golden Horde: Baba Tükles and the Conversion to Islam in Historical and Epic Tradition. University Park: Pennsylvania State University Press. 
Dickinson, Debra, and Michael Webber. 2007. Environment, Resettlement and Development, on the Steppes of Inner Mongolia, PRC. Journal of Development Studies 43(3): 537-61.

Dorungg-a, ed. 1998. Cinggis Qagan-u takil-un sudur orosiba-Monggol qaguci teüken nom-un baglag-a. Höhhot: Inner Mongolia People’s Press.

Elverskog, John. 2006. Our Great Qing: The Mongols, Buddhism and the State in Late Imperial China. Honolulu: University of Hawai' $i$ Press.

Fleming, Peter. 1936. News from Tartary: A Journey from Peking to Kashmir. New York: C. Scribner's Sons.

Golden, Peter. 1992. An Introduction to the History of the Turkic Peoples: Ethnogenesis and State-formation in Medieval and Early Modern Eurasia and the Middle East. Wiesbaden: Harrassowitz.

Grousset, René. 1970. Empire of the Steppes: A History of Central Asia, trans. Naomi Walford. New Brunswick: Rutgers University Press.

Hatto, Arthur T. 1989. Mongols in the Mid-Nineteenth Century Kirghiz Epic. Gedanke und Wirkung: Festschrift zum 90. Geburtstag von Nikolaus Poppe, ed. Walther Heissig and Klaus Sagaster, pp. 139-45. Wiesbaden: Harrassowitz.

— 1993. Reflections of a non-Mongolist on W. Heissig's Erzählstoffe. UralAltaische Jahrbucher 12:269-78.

Heissig, Walther. 1980. The Religions of Mongolia, trans. Geoffrey Samuel. Berkeley: University of California Press.

Jagchid, Sechin. 1988. Buddhism in Mongolia after the Collapse of the Yuan Dynasty. In Essays in Mongolian Studies, ed. Sechin Jagchid, pp. 121-27. Provo: Brigham Young University.

Kara, György. 2005. Books of the Mongolian Nomads: More than Eight Centuries of Writing Mongolian. Bloomington: Indiana University.

- 2000. Late Mediaeval Turkic Elements in Mongolian. In De Dunhuang à Istanbul: Hommage à James Russell Hamilton, ed. Louis Bazin and Peter Zieme, pp. 73-119. Silk Road Studies 5. Turnhout: Brepols.

Khidirbekughli, Doulatbek. 2004. Mysterious Eurasia: Thoughts in Response to Dr. Schoeberlein. Central Eurasian Studies Review 3(1): 4-5.

Kim, Hodong. 1999. The Early History of the Moghul Nomads: The Legacy of the Chaghatai Khanate. In The Mongol Empire and Its Legacy, ed. Reuven Amitai-Preiss and David O. Morgan, pp. 290-318. Leiden: Brill.

2004. Holy War in China. Stanford: Stanford University Press.

Kollmar-Paulenz, Karénina. 2003. Buddhism in Mongolia after 1990. Journal of Global Buddhism 4:18-34.

Kotkin, Stephen. 2007. Mongol Commonwealth? Exchange and Governance across the Post-Mongol Space. Kritika: Explorations in Russian and Eurasian History 8(3): 487-531.

Lattimore, Owen. 1930. High Tartary. Boston: Little, Brown. 1940. Inner Asian Frontiers of China. New York: American Geographical Society. 
Lehrman, Alexander. 2004. The Distinctive Factors of Central Eurasia: A Response to Professor Gleason. Central Eurasian Studies Review 3(1): 5-6.

Levi, Scott C. 2002. The Indian Diaspora in Central Asia and Its Trade, 1550-1900. Leiden: Brill.

Ligeti, Louis. 1973. Trésor des sentences: Subhâşitaratnanidhi de Sa-skya Pandita, traduction de Sonom Gara. Budapest: Akadémiai Kiadó.

Mawkhanuli, Talant. 2005. Jungar Tuvan Texts. Bloomington: Indiana University. Mongolica. 1994-2006. Table of Contents, Vols. 5-14.

Morgan, David. 1986. The Mongols. Oxford: Basil Blackwell.

Namsarai. 1984. Cing ulus-un üy-e-yin Monggol qosigu cigulgan. Tongliao: Inner Mongolia Youth Press.

Newman, John. 1998. Islam in the Kâlacakra Tantra. Journal of the International Association of Buddhist Studies 21(2): 311-71.

Oda Juten. 1978. Uighuristan. Acta Asiatica: Bulletin of the Institute of Eastern Culture 34:22-45.

Oxford English Dictionary/OED Online. http:/ / www.oed.com/ (accessed November 10, 2007).

Privratsky, Bruce G. 2001. Muslim Turkistan: Kazak Religion and Collective Memory. Richmond, Surrey: Curzon Press.

Sela, Ron. 2003. Ritual and Authority in Central Asia: The Khan's Inauguration Ceremony. Papers on Inner Asia, no. 37. Bloomington: Indiana University.

Shirendew, B., ed. 1973. Olon ulsyn mongolch erdemtnii II ikh khural. 2 vols. Ulaanbaatar: Academy of Sciences.

—_ ed. 1977-79. Olon ulsyn mongolch erdemtnii III ikh khural. 3 vols. Ulaanbaatar: Academy of Sciences.

Shogaito, Masahiro. 1991. On Uighur Elements in Buddhist Mongolian Texts. Memoirs of the Toyo Bunko 49:27-49.

Sinor, Denis. 1954. Central Eurasia. In Orientalism in History, ed. Denis Sinor, pp. 82-103. Cambridge: W. Heffner \& Sons.

1970. Inner Asia. In Orientalism in History, ed. Denis Sinor, pp. 93-119. 2nd ed. Bloomington: Indiana University Press.

— ed. 1990. Cambridge History of Early Inner Asia. Cambridge: Cambridge University Press.

Smith, Anthony D. 1986. The Ethnic Origins of Nations. Oxford: Basil Blackwell.

South Mongolian Human Rights Information Center. http://www.smhric. org/SMW_content13.htm (accessed June 29, 2004).

Sperling, Elliot. 1992. Notes on Reference to 'Bri-gung-pa-Mongol Contact in the Late Sixteenth and Early Seventeenth Centuries. Tibetan Studies, Proceedings of the 5th Seminar of the International Association of Tibetan Studies, NARITA 1989:741-50.

Subtelny, Maria E. 2007. Timurids in Transition: Turko-Persian Politics and Acculturation in Medieval Iran. Leiden: Brill.

Szuppe, Maria. 2004. Circulation des letters et circles littéraires entre Asie 
centrale, Iran et Inde du Nord (XVe-XVIII ${ }^{\mathrm{e}}$ siècle). Annales: Histoire, Sciences Sociales 59:997-1018.

Togochog, Enhebatu. 2002. Statement by Enhebatu Togochog, President, Southern Mongolian Human Rights Information Center, to the Congressional-Executive Commission on China. http://www.cecc.gov/ pages / roundtables / 080502 / togochog.php (accessed June 29, 2004).

Tsoloo, J., ed. 1967. Biography of Caya Pandita in Oirat Characters. Ulaanbaatar: Academy of Sciences.

—, ed. 1961-62. Olon ulsyn mongol khel bichgiin erdemtnii ankhdugaar ikh khural. 4 vols. Ulaanbaatar: Academy of Sciences.

Tümen, D. 2006. Archaeology of the Chinggis Period. Mongolia Society/ ACMS annual meeting poster session, San Francisco, April 7.

UNESCO. 1998- . History of Civilizations of Central Asia. http:/ / www.unesco. org/culture/asia/ (accessed November 17, 2007).

Waugh, Louisa. 2003. Hearing Birds Fly: A Nomadic Year in Mongolia. London: Time-Warner Books, UK.

Williams, Dee Mack. 2002. Beyond Great Walls: Environment, Identity, and Development on the Chinese Grasslands of Inner Mongolia. Stanford: Stanford University Press.

Yang, Haiying. 2001. The Politics of Writing History in China: A Comparison of Official and Private Histories. Inner Asia 3(2): 127-51. 